\title{
The Relationship Between Attachment Styles, Emotional Intelligence, and Self-esteem in Only-child Families and Two- children Families
}

\section{La relación entre los estilos de apego, la inteligencia emocional y la autoestima en familias con hijos únicos y familias con dos hijos}

\author{
Noora Rahmani \\ MA, Near East University, Tehran, Marzdaran Blv, Aftab St, Tehran, Iran. \\ ORCID: 0000-0001-6142-1077 \\ Ezgi Ulu \\ Assist Prof, Psychology, Faculty of Arts \& Science, Near East University, North Cyprus, \\ Mersin 10, Turkey. \\ ORCID: 0000-0001-6418-8995
}

*Correspondencia

Email: ezgi.ulu@neu.edu.tr

(c) Universidad San Ignacio de Loyola, Vicerrectorado de Investigación, 2020.

Este artículo se distribuye bajo licencia CC BY-NC-ND 4.0 Internacional (http://creativecommons.org/licenses/by-ncnd/4.0/). 


\begin{abstract}
Emotional intelligence, attachment style, and self-esteem are important variables in social interaction that can affect the social relationship. Also having one child is an important issue in which parents are worried about it which is the adolescent's single families have weaknesses in social relationships and interaction? In this study, the researcher tries to investigate the relationship between emotional intelligence, attachment style, and self-esteem in single-child and two-children adolescents aged range 13-17 (male and female). The current research used a quantitative survey study and used three questionnaires; inventory of parent and peer attachment (IPPA), inventory of trait emotional intelligence questionnaire (TEIQue), self-esteem inventory (TSI), and the socio-demographic form developed by the researcher. The participant was 228 adolescents 13-17 years old (male and female). And for the relationship between the three variables the researcher used regression and correlation and used t-test and ANOVA for comparison of socio-demographic (only or two children, gender, and age) with these variables. The result of this study showed that there is a significant relationship between emotional intelligence and self-esteem. Also, there were no significant differences between single-child and two-children in emotional intelligence, attachment style, and self-esteem. In differences of gender (girl and boy), there was a statistically significant in self-esteem and emotional intelligence between girls and boys but not in an attachment. Also in age, there were statistically significant differences in attachment between 13 and 16. Parents, therapists, and adolescent counselors should be aware of the importance of emotional intelligence and self-esteem and they should be careful about the single-child and their abilities.
\end{abstract}

Keywords: Emotional intelligence, Attachment style, Self-esteem, single-child

\title{
Resumen
}

La inteligencia emocional, el estilo de apego y la autoestima son variables importantes en la interacción social que pueden afectar la relación social. También tener un hijo es un tema importante en el que los padres están preocupados, ¿cuáles son las familias solteras del adolescente que tienen debilidades en las relaciones e interacciones sociales? En este estudio, el investigador intenta investigar la relación entre la inteligencia emocional, el estilo de apego y la autoestima en adolescentes con un solo hijo y con dos hijos de entre 13 y 17 años (hombres y mujeres). La investigación actual utilizó un estudio de encuesta cuantitativo y utilizó tres cuestionarios; Inventario de apego de padres y pares (IPPA), Inventario de rasgo cuestionario de inteligencia emocional (TEIQue), Inventario de autoestima (TSI) y la forma sociodemográfica desarrollada por el investigador. El participante fue 228 adolescentes de 13 a 17 años (hombres y mujeres). Y para la relación entre las tres variables, el investigador utilizó regresión y correlación y utilizó la prueba t y ANOVA para la comparación sociodemográfica (solo o dos hijos, sexo y edad) con estas variables. El resultado de este estudio mostró que existe una relación significativa entre la inteligencia emocional y la autoestima. Además, no hubo diferencias significativas entre un solo hijo y dos hijos en inteligencia emocional, estilo de apego y autoestima. En las diferencias de género (niña y niño), hubo una estadísticamente significativa en la autoestima e inteligencia emocional entre niñas y niños pero no en un apego. También en la edad, hubo diferencias estadísticamente significativas en el apego entre los 13 y los 16 años. Los padres, terapeutas y consejeros de adolescentes deben ser conscientes de la importancia de la inteligencia emocional y la autoestima y deben tener cuidado con el hijo único y sus habilidades.

Palabras clave: inteligencia emocional, estilo de apego, autoestima, hijo único

\section{Introduction}

In the study of attachment, emotional intelligence, and self-esteem affect social interaction there are some studies. Attachment style in a secure type has a positive effect on the social relationship and it talks if adolescence has a secure attachment with mother (first caregiver) they have a better 
relationship in social with peers or others (Buist, Deković, Meeus\& van Aken, 2004). Also, emotional intelligence, in one study the result showed that adolescents whose emotional intelligence is at a high level, have a good relationship and social interaction in society (Poulou, 2014). And, about self-esteem in one study, the result showed that adolescents with a high level of self-esteem have a better relationship with peers and other people and they have a good interaction in social (Rosenberg, Schooler \& Schoenbach, 1989).

According to the attachment Gander, George, Pokorny \& Buchheim (2017) said that attachment is the important relationship between child and parents, especially between child and mother in terms of their cognitive-developmental, social, and emotional that it affects well-being. In one of the studies in the literature, it is found that children with childhood secure attachment have a positive interaction in relationships in their early adolescence and show reduced problematic behavior (Laible \& Thompson,2000). Also, regarding Emotional intelligence, there is a study by Salovey \& Pizarro (2003) that they believe is the ability to perceive understand emotions, thoughts, and manage emotions. Emotional intelligence is an important social skill also, Sun, Liu \&Yu (2019) with emotional intelligence, the person can utilize affect-laden information and reason about the emotions to guide one's thinking as well as actions. In the concept of selfesteem, in one of the studies in the literature, it is found that there are two dimensions and described them as a cognitive dimension of global self-esteem, the first one is self-competence and the other one is self-liking (Tafarodi and Swann, 1995). Self-competence is the overall positive or negative orientation toward oneself as a source of efficacy and power and the other one is self-liking is one of the variables which can evaluative the experience of oneself as a good or bad person in society (Bosson \& Swann, 1999).

In the words of Erikson (1959) adolescence "is only after a reasonable sense of identity has been established that real intimacy with the other sex is possible". Also, for the adolescence list, Deković, Meeus \& van Aken (2004) defined that adolescence is such an important time of life, during which the individuals learn how to become autonomous and independent from family and siblings and also, start to confront the task of developing their identity. It is hard for them because they do that while they are involved in close relationships with parents, siblings, and peers.

The concept of only-child in most of the families in which they have a special situation and they can't have more than one child is an important issue because most of them think onlychild is bad or it has harm for the child to be alone (Falbo, 1977).

\section{Problem Statement}

These days having one child can be an issue that most families think about they don't know actually whether it is good or bad. The important problem is most families decide to have one child but they are worried about the consequences of this decision and they don't know whether that is harmful to their child's future or not? Cameron, Erkal, Gangadharan \& Meng (2013) believe that having one child can be a problem for that child and even society and the one-child have weaknesses more than the two children or more families. In some studies, by Sun, Liu \& Yu (2019) mentioned that emotional intelligence has a relationship with social skills and interactions. Another one about attachment mentioned that attachment can affect social relationships and interaction (Eikenæs, Pedersen \& Wilberg, 2016). And also, Luo \& Lin (2018) mentioned that self-esteem affects social behavior and interaction.

This study tries to use an attachment, emotional intelligence, and self-esteem variables because these three variables are important in social interaction and relationships in social interaction. So because of that, the researcher chooses them for two types of families, and also the researcher wants to know is there any relationship between attachment, emotional intelligence, and self-esteem? 
This research aim is to find out whether there are any differences in emotional intelligence, attachment, and self-esteem, between the only children families and two children families aged 13 to 17 years old in Tehran (Iran)? The researcher wants to understand, are there any differences between single-child and two-children families in attachment, emotional intelligence, and self-esteem or not. So the following research questions will guide the study:

1. Is there a relationship between one-child and two-children on attachment, emotional intelligence, and self-esteem of the participants?

2. Is there a relationship between gender and emotional intelligence, attachment style, and self-esteem levels of the participants?

3. Is there a relationship between age and emotional intelligence, attachment style, and self-esteem levels of the participants?

4. Is there any relationship between attachment, emotional intelligence, and self-esteem of the participants?

\section{Methodology \\ Design}

The current study used a survey study, quantitative that it means in this method the researcher tries to collect the data and use the numbers for analyzing the mathematical and statistical way to show the result of the study (Stott, Adang, Livingstone \& Schreiber, 2008). Also, the researcher used the correlational design which in this method the researcher looking at the relationships between two or more variables (Curtis, Comiskey \& Dempsey, 2016).

\section{Population and the Sample}

The population is adolescents of single-child and two-children families of Iran (Tehran) which 228 adolescents (65 single-child and 163 two-children adolescents) attended in filling the questionnaire voluntarily. The researcher chooses the participants randomly that which means without method or any organization and conscious decisions the researcher chooses the participants (Consolvo \& Walker, 2003), from 4 private high schools in Tehran (Iran).

\section{Materials}

In this study, we use the Trait Emotional Intelligence Questionnaire (TEIQue) for emotional intelligence, Inventory of Parent and Peer Attachment (IPPA) for attachment, and, the self-esteem inventory (TSI) for self-esteem, and the last one is socio-demographic which here describes it one by one:

Inventory of Parent and Peer Attachment (IPPA) This measurement was developed by Armsden \& Greenberg (1987). And, comprise three forms for father, mother, and peer, each part has 25 items which aim is to find out the score of attachment for parents and peers. For attachment, the score for adolescents is between low, medium, and high (Pace, San Martini \& Zavattini, 2011). The reliability of this questionnaire was calculated using Cronbach's alpha and split test, ranging from $73 \%$ to $94 \%$. The validity of the questionnaire in a re-test method was $86 \%$ for the sample of 27 subjects aged 18-20 during a three week (Khojasteh, Mombeini, \& Aslani, 2013).

Inventory of Trait Emotional Intelligence Questionnaire (TEIQue) This measurement was developed by Petrides (2009) and it was used to conceptualize emotional and emotional intelligence as a personality trait. In this test, there are 30 items that participants should 
answer and it has a seven-point Likert scale. Generally, the total score can be between low middle and high scores (Petrides, 2009). The reliability in the study by Narimani, Mahmoudi \& Malekshahifar (2009), was 0.84 and for its subscales namely emotion regulation (0.76), and emotion assessment and emotion regulation (0.55),

Inventory of The self-esteem inventory (TSI) This measurement was developed by Coopersmith (Kokenes, 1978). This measurement is about self-esteem which measures the level of self-respect and believing in self this questioner has 58 questions that participants must choose one of these two like me or unlike me. If the total score is more than 25.4 it means they have good self-esteem but if they get lower than 25.4 it means they have low self-esteem (Francis, 1997).

The reliability of TSI in a study by Tamanaifar, Sedighi Arfai \& Salami Mohammad Abadi (2011) consistency in measuring everything it measures, and the result is obtained under the same conditions when the Cronbach's alpha coefficient of self-esteem is 0.88 .

Socio-Demographic Form is the questionnaire was developed by the researcher that aimed at collecting information of respondents such as gender, single-child, or two-children and age.

\section{Data collection procedure}

For collecting data first of all the researcher et all permission and inform the parents of adolescents and after getting all acceptance from parents and adolescents to explain the aim of the study for participants they have 25 minutes to fill the questionnaire. Participants are from 4 high schools in Tehran in Iran.

\section{Data analysis procedures}

For this study, the researcher uses SPSS for analyzing the data. The regression and correlation analysis for the relationship between attachment and emotional intelligence, and self-esteem. The researcher also uses the t-test to evaluate the mean and variance of two groups of students (the only-child and two-children) and gender (girl and boy) and compare them and find what Is the relationships between these variables and group of adolescents. Because of multivariate analysis for age (13-17), the researcher uses ANOVA.

\section{Result}

Regarding the aim of the study, the researcher tries to find differences between the first and second child in three variables of Attachment, emotional intelligence, and self-esteem. Also, the differences between gender and age. So, the result of the analysis for the data shows the following foundlings:

Table 1.Comparison of Attachment style, Emotional intelligence, and Self-esteem in two groups of single-child and two-children

\begin{tabular}{|c|c|c|c|c|c|c|}
\hline Variable & Group & $\mathbf{N}$ & $\begin{array}{c}\text { Mean } \\
\text { Std. } \\
\text { Deviation }\end{array}$ & $\begin{array}{c}\text { Std. } \\
\text { Deviation }\end{array}$ & $\mathbf{T}$ & p \\
\hline \multirow{2}{*}{ Self-esteem } & single-child & 65 & 31.66 & 7.04 & 1.255 & .211 \\
\cline { 2 - 7 } & Two-children & 163 & 30.31 & 7.43 & .551 & .582 \\
\hline & single-child & 65 & 113.15 & 22.5 & & \\
\hline
\end{tabular}




\begin{tabular}{|c|c|c|c|c|c|c|}
\hline $\begin{array}{c}\text { Emotional } \\
\text { Intelligence }\end{array}$ & Two-children & 163 & 111.52 & 19.07 & & \\
\hline \multirow{2}{*}{ Attachment } & single-child & 65 & 244.56 & 26.08 & \multirow{2}{*}{.378} & .706 \\
\cline { 2 - 8 } & Two-children & 163 & 243.15 & 25.29 & \\
\hline
\end{tabular}

As it can be seen about the comparison of self-esteem, emotional intelligence, and attachment style in two groups of adolescents, the result shows that there were no statistically significant differences in self-esteem, emotional intelligence, and attachment in single-child and two-children $(\mathrm{p}>0.05)$.

Table 2. Comparison of Attachment style, Emotional intelligence, and Self-esteem in gender

\begin{tabular}{|c|c|c|c|c|c|c|}
\hline Variable & Sex & $\mathbf{N}$ & Mean & SD & $\mathbf{T}$ & p \\
\hline \multirow{2}{*}{ Self-esteem } & Girl & 111 & 32.63 & 6.93 & \multirow{2}{*}{4.02} & \multirow{2}{*}{$.000^{*}$} \\
\hline & Boy & 117 & 28.85 & 7.25 & & \\
\hline \multirow{2}{*}{$\begin{array}{l}\text { Emotional } \\
\text { Intelligence }\end{array}$} & Girl & 111 & 121.11 & 15.62 & \multirow{2}{*}{7.49} & \multirow{2}{*}{$.000^{*}$} \\
\hline & Boy & 117 & 103.33 & 20.04 & & \\
\hline \multirow{2}{*}{ Attachment } & Girl & 111 & 245.25 & 22.67 & \multirow{2}{*}{.984} & \multirow{2}{*}{.326} \\
\hline & Boy & 117 & 241.94 & 27.87 & & \\
\hline
\end{tabular}
${ }^{*} \mathrm{p} \leq 0.01$

The first variable is self-esteem that the result in table 2 shows the mean in girls $(32.63 \pm$ $6.93)$ is higher than boys $(28.85 \pm 7.25)$. A comparison of self-esteem in the gender of adolescents using the t-test method revealed that there were statistically significant differences between selfesteem score and gender of adolescents $(\mathrm{t}=4.02, \mathrm{p} \leq 0.01)$.

The second variable is emotional intelligence and the mean in girls $(121.11 \pm 15.62)$ is higher than boys $(103.33 \pm 20.04)$. And the comparison of emotional intelligence in the gender that using the t-test method shows that there were statistically significant differences between emotional intelligence score and gender of adolescents $(t=7.49, \mathrm{p} \leq 0.01)$.

And the last one is an attachment and the result shows that girls have a higher score $(245.25 \pm 22.67)$ than boys $(241.94 \pm 27.87)$. The comparison of attachment in the gender by $t-$ test method shows that there were no statistically significant differences between attachment score and gender of adolescents $(t=0.984, p>0.05)$.

Table 3. Comparison of Attachment style, Emotional intelligence, and Self-esteem in the age

\begin{tabular}{|c|c|c|c|c|c|}
\hline & Sum of squrs & df & Mean square & F & p \\
\hline Self-esteem & 300.958 & 4 & 75.240 & \multirow{2}{*}{1.408} & \multirow{2}{*}{.323} \\
\hline Between groups & 11917.160 & 223 & 53.440 & & \\
\hline Within groups & 12218.118 & 227 & & & \\
\hline Total & 730.869 & 4 & 182.717 & \multirow{2}{*}{.449} & \multirow{2}{*}{.773} \\
\hline Emotional intelligence & 90779.114 & 223 & 407.081 & & \\
\hline Between groups & 91509.982 & 227 & & \multirow{2}{*}{$.016^{*}$} \\
\hline Within groups & 7791.757 & 4 & 1947.939 & \multirow{2}{*}{3.113} & \\
\hline Total & 139522.502 & 223 & 625.661 & & \\
\hline Attachment & 147314.259 & 227 & & & \\
\hline Between groups & Within groups & & & \\
\hline Total &
\end{tabular}

$* \mathrm{p} \leq 0.05$ 
As can be seen in table 3 the comparison of self-esteem using the ANOVA method reveal that there were no statistically significant differences between groups of ages $(f=1.408, p>.323)$.

Also, the comparison of emotional intelligence using the ANOVA method reveals that there were no statistically significant differences between groups of ages $(f=.449, p>.773)$.

For comparison of attachment using the ANOVA, the method reveals that there were statistically significant differences between groups of ages $(f=3.113, p \leq .016)$. Because the $p$ is significant, to find the exact result in a group of ages with using Post hoc test in the Tukey test method and the result shows that there was a significant difference between age thirteen (252.028) and sixteen (235.055). So it means the mean of attachment in adolescents with thirteen age is higher than adolescents with sixteen years old.

Table 4. The correlation between Self-Esteem, Emotional Intelligence, and Attachment

\begin{tabular}{|c|c|c|c|c|}
\hline & & Emotional intelligence & Self-esteem & Attachment \\
\hline \multirow{3}{*}{$\begin{array}{c}\text { Emotional } \\
\text { intelligence }\end{array}$} & $\mathrm{r}$ & & $.665^{* * *}$ & .122 \\
\cline { 2 - 5 } & $\mathrm{p}$ & & $\mathbf{. 0 0 0}$ & .067 \\
\cline { 2 - 5 } & $\mathrm{N}$ & & 228 & 228 \\
\hline \multirow{3}{*}{ Self-esteem } & $\mathrm{r}$ & & & $.154^{*}$ \\
\cline { 2 - 5 } & $\mathrm{p}$ & & & $\mathbf{. 0 2 0}$ \\
\cline { 2 - 5 } & $\mathrm{N}$ & & & 228 \\
\hline \multirow{3}{*}{ Attachment } & $\mathrm{r}$ & & & \\
\cline { 2 - 5 } & $\mathrm{p}$ & & & \\
\cline { 2 - 5 } & $\mathrm{N}$ & & & \\
\hline
\end{tabular}

**. Correlation is significant at the 0.01 level (2-tailed).

*. Correlation is significant at the 0.05 level (2-tailed).

Based on Pearson's coefficient, there was a statistically significant relationship between self-esteem and emotional intelligence $(\mathrm{p} \leq 0.01)$. Also, there was a statistically significant relationship between self-esteem and attachment $(\mathrm{p} \leq 0.05)$. But there was no statistically significant relationship between emotional intelligence and attachment $(\mathrm{p}>0.05)$. According to the linear regression model, attachment and self-esteem can be used as predictive (independent) variables. To predict Emotional intelligence as dependent by two other variables, by regression analysis and enter method. Only self-esteem is appropriate for prediction, which is consistent with the correlation coefficient reported above.

Table 5. Regression analysis summary for Self-esteem, Emotional intelligence, and Attachment

\begin{tabular}{|c|c|c|c|c|}
\hline Variable & $\mathbf{B}$ & $\boldsymbol{\beta}$ & $\mathbf{t}$ & $\mathbf{p}$ \\
\hline Constant & 52.575 & & 5.260 & $.000^{*}$ \\
\hline Attachment & .016 & .020 & .397 & .692 \\
\hline Self-esteem & 1.810 & .662 & 13.127 & $.000^{*}$ \\
\hline
\end{tabular}

a. Dependent variable: Emotional intelligence

${ }^{*} \mathrm{p} \leq 0.05$

Table 6 as it can be seen shows that there is a statistically significant relationship between emotional intelligence and self-esteem, in which $44 \%$ of the variables of the dependent variables are expressed from the regression model. $44 \%$ of the changes in emotional intelligence can be explained by self-esteem.

\section{Discussion}

The present study primarily aimed to investigate the relationship between self-esteem, emotional intelligence, and attachment. Also, the researcher tries to examine how the adolescent's 
demographic characteristics such as gender, single-child, or two-children and age were associated with influencing self-esteem, emotional intelligence, and attachment.

Several studies mentioned that there was a statistically significant relationship between self-esteem and attachment. In one study by Shoshani, Nakash, Zubida \& Harper (2014) the outcomes mentioned that there was a significant relationship between self-esteem and attachment in adolescents, which means that secure attachment affects self-esteem, social relationship, and peer support. So in the recent study, the most important note is adolescents with secure attachments had higher self-esteem and it is the same as the result of the article which was done by Shoshani, Nakash, Zubida \& Harper (2014). Also, another study by Menon, Moyes \& Bradley (2018) notice that there is a relationship between self-esteem and insecure attachment in narcissism.

Besides, self-esteem had a relationship with emotional intelligence and it showed that if self-esteem is high the emotional intelligence is high too. In fact, self-esteem can affect their emotional intelligence (Khan, Ilyas \& Fatima, 2015), So in a recent study, the researcher also confirms that adolescents with a high level of self-esteem have a high level of emotional intelligence.

In the study of emotional intelligence and attachment, there are some studies that they mentioned there is a significant relationship between these two variables, and other studies mentioned that there is no significant relationship between emotional intelligence and attachment (Naguiat, 2018; Eke Zysberg, Kelmer \& Mattar, 2019). But in this study, the researcher finds out that there is no statistically significant relationship between emotional intelligence and attachment. This means none of these two variables in this sample has no effect on each other, and the outcomes for this study are near to the study by Eke Zysberg, Kelmer \& Mattar (2019).

In the concept of single-child in this study, the researcher finds that there are no statistically significant differences between single-child and two children. And this result can confirm the result of the study by Kwan \& Ip (2009), in which the result showed that only children were more successful in academic performance, achievement, and self-esteem, and also the only children had fewer behavioral problems like; suicide, self-injury, and fighting. So contrary to popular belief in the ability of single-child which can be lower than two-children or multiple children, the result of this study showed that adolescents that are only-children have no significant differences with adolescents of two-children families. And even the mean of self-esteem and emotional intelligence in adolescents of only-child families is higher than two-children.

In the subject of gender in one study by Andrei, Mancini, Mazzoni, Russo \& Baldaro (2015) about emotional intelligence, the result showed that emotional intelligence is higher in girls instead of boys. Also, another study by Daňsová, Bouša, Lacinová, Macek, Cígler \& Tomášková (2019) about self-esteem showed that there is a significant difference between girls and boys, the result showed that self-esteem is higher in girls which it is lower in boys.

In this study Also the result is the same as the result of previous researches. In the concept of self-esteem, the mean of girls is higher than boys, and there were statistically significant differences between girls and boys. Also in emotional intelligence, in a study by Andrei, Mancini, Mazzoni, Russo \& Baldaro (2015) there are statistically significant differences between boys and girls, and it means the level of emotional intelligence in girls is higher than boys. The outcomes of this study confirm the result of the study by Daňsová, Bouša, Lacinová, Macek, Cígler \& Tomášková (2019). Also in a study of literature one study by Apell, Marttunen, Fröjd \& Kaltiala (2019) finds that self-esteem in girls is higher than boys, which means the statistically significant differences between males and females is the same as the outcomes of this study. 
In the study of age in one study by Daňsová, Bouša, Lacinová, Macek, Cígler \& Tomášková (2019) the result showed that there was no significant relationship between age and self-concept. In the study of age and attachment, Kokkinos (2013), studied and the result showed that the mean of attachment in younger adolescents is higher than the older. In another study by Grant-Marsney, Grotevant \& Sayer (2015), the result showed that there were no statistically significant in attachment and age. Also in one research by Pascuzzo \& Moss (2013), the result showed the same outcome as the previous study in which there was no statistically significant relationship between age and attachment in adolescents.

In this study, the result shows that there are statistically significant differences in the mean of attachment and ages which the outcomes show that younger adolescents (age 13) have a higher score in the mean of attachment than older adolescents (age 16) so it is as same as the result which done before by Kokkinos (2013).

\section{Conclusion}

The study related to self-esteem, emotional intelligence, and attachment in adolescents of singlechild and two-children families in the city of Iran, Tehran. The result of the analysis for the data shows the following foundlings:

In this study, the result shows that there was a statistically significant relationship between self-esteem and emotional intelligence, and self-esteem and attachment. But there was no statistically significant relationship between emotional intelligence and attachment. In differences of gender (girl and boy), there was a statistically significant in self-esteem and emotional intelligence between girls and boys but not in an attachment. In a comparison of two groups of adolescents (single-child and two-children), there were no statistically significant differences. Also in age, there were statistically significant differences in attachment between 13 and 16.

\section{Recommendations}

The study recommended the following:

In the importance of self-esteem and emotional intelligence as the result shows in this study can be useful for parentings, parents should have attention to the important role of selfesteem and emotional intelligence because improving the self-esteem and emotional intelligence in children, and especially adolescents can affect their social interactions and lifestyle. Also, the views of parents, families, teachers, and society should be changed about only children and their abilities. It is important to know that only children can be like two children and multiple children and even better. It means that the ability of the only child and things like self-esteem, emotional intelligence can be near the same as the two children or multiple children. In follower of the result in this study for single-child and two-children families, teachers, and psychologists should understand that there are no significant differences between single-child and two-children. So it should be considered by teachers, families, and teachers in the educational program and abilities of single-child.

The study should be expanded to other cities in Iran. Also, it should be replicated with a large sample in which the researcher can generalize the result. And it should be replicated with a large sample of single-child because it can't be generalized and it should be done in different cultures and countries to see if the result can be the same or not.

\section{References}


- Andrei, F., Mancini, G., Mazzoni, E., Russo, P. M., \& Baldaro, B. (2015). Social status and its link with personality dimensions, trait emotional intelligence, and scholastic achievement in children and early adolescents. Learning and Individual Differences, 42, 97-105.

- Apell, S., Marttunen, M., Fröjd, S., \& Kaltiala, R. (2019). Experiences of sexual harassment are associated with high self-esteem and social anxiety among adolescent girls. Nordic journal of psychiatry, 73(6), 365-371.

- Armsden, G. C., \& Greenberg, M. T. (1987). The inventory of parent and peer attachment: Individual differences and their relationship to psychological well-being in adolescence. Journal of youth and adolescence, 16(5), 427-454.

- Bosson, J. K., \& Swann Jr, W. B. (1999). Self-liking, self-competence, and the quest for selfverification. Personality and Social Psychology Bulletin, 25(10), 1230-1241.

- Buist, K. L., Deković, M., Meeus, W. H., \& van Aken, M. A. (2004). Attachment in adolescence: A social relations model analysis. Journal of Adolescent research, 19(6), 826-850.

- Cameron, L., Erkal, N., Gangadharan, L., \& Meng, X. (2013). Little emperors: behavioral impacts of China's One-Child Policy. Science, 339(6122), 953-957.

- Consolvo, S., \& Walker, M. (2003). Using the experience sampling method to evaluate ubicomp applications. IEEE pervasive computing, 2(2), 24-31.

- Curtis, E. A., Comiskey, C., \& Dempsey, O. (2016). Importance and use of correlational research. Nurse Researcher, 23(6).

- Daňsová, P., Bouša, O., Lacinová, L., Macek, P., Cígler, H., \& Tomášková, Z. (2019). Subjective health complaints in fifteen-year-old Czech adolescents: The role of self-esteem, inter-parental conflict, and gender. Studia Psychologica, 61(4), 258-270.

- Eikenæs, I., Pedersen, G., \& Wilberg, T. (2016). Attachment styles in patients with avoidant personality disorder compared with social phobia. Psychology and Psychotherapy: Theory, Research and Practice, 89(3), 245-260.

- Erikson, E. H. (1959). Identity and the life cycle: Selected papers.

- Falbo, T. (1977). The only child: A review. Journal of Individual Psychology, 33(1), 47.

- Francis, L. J. (1997). Coopersmith's model of self-esteem: Bias toward the stable extravert?. The Journal of social psychology, 137(1), 139-142.

- Gander, M., George, C., Pokorny, D., \& Buchheim, A. (2017). Assessing attachment representations in adolescents: discriminant validation of the adult attachment projective picture system. Child Psychiatry \& Human Development, 48(2), 270-282.

- Grant-Marsney, H. A., Grotevant, H. D., \& Sayer, A. G. (2015). Links between Adolescents' Closeness to Adoptive Parents and Attachment Style in Young Adulthood. Family relations, 64(2), 221-232.

- Kwan, Y. K., \& Ip, W. C. (2009). Life satisfaction, perceived health, violent and altruistic behaviour of Hong Kong Chinese adolescents: Only children versus children with siblings. Child indicators research, 2(4), 375-389.

- Kokenes, B. (1978). A factor analytic study of the Coopersmith Self-Esteem Inventory. Adolescence, 13(49), 149.

- Kokkinos, C. M. (2013). Bullying and victimization in early adolescence: Associations with attachment style and perceived parenting. Journal of School Violence, 12(2), 174-192.

- Khan, Z. H., Ilyas, K., \& Fatima, B. (2015). Emotional intelligence: A key factor for self-esteem and neurotic behavior among adolescence of Karachi, Pakistan. Indian Journal of Positive Psychology, 6(2), 171.

- Khojasteh, M. R., Mombeini, J., \& Aslani, K. H. (2013). A comparison of attitude toward marriage, attitude toward divorce and peer attachment of male high school students in divorced and intact families.

- Laible, D. J., \& Thompson, R. A. (2000). Mother-child discourse, attachment security, shared positive affect, and early conscience development. Child development, 71(5), 1424-1440. 
- Liu, Y., Fei, L., Sun, X., Wei, C., Luo, F., Li, Z., ... \& Lin, X. (2018). Parental Rearing Behaviors and Adolescent's Social Trust: Roles of Adolescent Self-esteem and Class Justice Climate. Journal of Child and Family Studies, 27(5), 1415-1427.

- Menon, M., Moyes, H. C., \& Bradley, C. M. (2018). Interactive influences of narcissism and self-esteem on insecure attachment in early adolescence. The Journal of Early Adolescence, 38(7), 966-987.

- Narimani, M., Mahmoudi, N., \& Malekshahifar, M. (2009). Emotional Intelligence and Attachment Style in Children with and without Stuttering. Journal of Exceptional Children, 9(2), 155-162.

- Naguiat, E. S. (2018). Romantic Attachment Style and Emotional Intelligence of Adolescents with Migrant and Non-Migrant Mothers: A Correlational Study. IJAME.

- Pace, C. S., San Martini, P., \& Zavattini, G. C. (2011). The factor structure of the Inventory of Parent and Peer Attachment (IPPA): A survey of Italian adolescents. Personality and Individual Differences, 51(2), 83-88.

- Pascuzzo, K., Cyr, C., \& Moss, E. (2013). Longitudinal association between adolescent attachment, adult romantic attachment, and emotion regulation strategies. Attachment \& Human Development, 15(1), 83-103.

- Petrides, K. V. (2009). Psychometric properties of the trait emotional intelligence questionnaire (TEIQue). In Assessing emotional intelligence (pp. 85-101). Springer, Boston, MA.

- Poulou, M. S. (2014). How are trait emotional intelligence and social skills related to emotional and behavioral difficulties in adolescents?. Educational Psychology, 34(3), 354-366.

- Rosenberg, M., Schooler, C., \& Schoenbach, C. (1989). Self-esteem and adolescent problems: Modeling reciprocal effects. American sociological review, 1004-1018.

- Salovey, P., \& Pizarro, D. A. (2003). The value of emotional intelligence (pp. 263-278). Na.

- Shoshani, A., Nakash, O., Zubida, H., \& Harper, R. A. (2014). Mental health and engagement in risk behaviors among migrant adolescents in Israel: The protective functions of secure attachment, self-esteem, and perceived peer support. Journal of Immigrant \& Refugee Studies, 12(3), 233-249.

- Stott, C., Adang, O., Livingstone, A., \& Schreiber, M. (2008). Tackling football hooliganism: A quantitative study of public order, policing and crowd psychology. Psychology, public policy, and law, 14(2), 115.

- Sun, J., Liu, Q., \& Yu, S. (2019). Child neglect, psychological abuse, and smartphone addiction among Chinese adolescents: The roles of emotional intelligence and coping style. Computers in Human Behavior, 90, 74-83.

- Tafarodi, R. W., \& Swann Jr, W. B. (1995). Self-linking and self-competence as dimensions of global self-esteem: Initial validation of a measure. Journal of personality assessment, 65(2), 322-342.

- Tamanaifar, M. R., Sedighi Arfai, F., \& Salami Mohammad Abadi, F. (2011). The relationship of emotional intelligence, self-concept and self-esteem to academic achievement. Quarterly journal of research and planning in higher education, 16(2), 99-113.

- Zysberg, L., Kelmer, G., \& Mattar, L. (2019). Emotional intelligence, attachment and satisfaction with romantic relationships among young adults: a brief report. Psychology, 10(05), 694. 